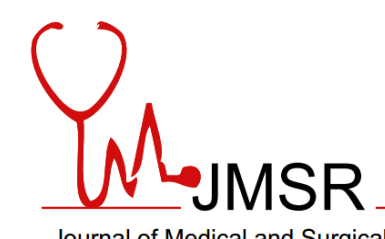

Journal of Medical and Surgical Research

\title{
IMPACTS OF COVID-19 PANDEMIC ON THE PSYCHOLOGICAL WELL BEING OF STUDENTS IN A NIGERIAN UNIVERSITY
}

\author{
Ajibola Idowu*, Damilola Akinola Olawuyi, Chioma Olive Nwadioke \\ Department of Community Medicine, Bowen University, Iwo, Nigeria.
}

\section{ABSTRACT}

The novel Covid-19 pandemic has caused disruption of several activities globally. It has resulted in lockdown of economic activities in most countries including Nigeria. The effects of the pandemic and the associated lockdown on the mental health status of Nigerian students have not taken into perspective in the control efforts.

This study was conducted to assess the burden of the psychological problems associated with COVID-19 pandemic and coping strategies among students at Bowen University, Iwo (BUI), Nigeria. A cross-sectional survey was conducted, and multi-stage sampling technique employed to recruit 433 eligible respondents. Validated online selfadministered, semi-structured questionnaire was used to collect relevant information from respondents. Appropriate summary statistics were carried out, and Binary logistic regression model was developed to examine protective/riskfactors of decreased mental wellbeing among the respondents. Mean age of the respondents was $20.11 \pm 2.9$ years, almost three-quarter $(72.7 \%)$ of them were females. In all, 55.0\% of the respondents had decreased psychological wellbeing because of the lockdown. Protective factors against decreased mental wellbeing included online catting with friends/watching films $(\mathrm{OR}=0.22,95 \% \mathrm{CI}=1.37-3.59)$, and participating in online vocational training $(\mathrm{OR}=0.25$, $95 \% \mathrm{CI}=0.25-0.61)$. The odds of decreased mental wellbeing was significantly higher in students who indicated a need for substance use as coping strategy $(\mathrm{OR}=1.50,95 \% \mathrm{CI}=0.55-4.05)$, and those who were not satisfied with online teaching method $(\mathrm{OR}=5.34,95 \% \mathrm{CI}=4.13-9.18)$. The mental health impacts of COVID-19 on the Nigerian students is huge. Thus, psychological wellbeing of the Nigerian students should be taken into cognizance and prioritized in the post-COVID-19 national rebuilding strategies.

Key Words: Covid-19; Determinants; Depression; Mental wellbeing; Mental disorders; Suicide.

\section{Corresponding Author:}

Dr Ajibola Idowu

Affiliation: Department of Community Medicine, Bowen University, Iwo, Nigeria.

E-mail: idajibola@yahoo.com

Tel: +2348137974759

Copyright $($ ) 2012- 2020 Dr Ajibola Idowu. This is an open access article published under Creative Commons Attribution -Non Commercial- No Derives 4.0 International Public License (CC BY-NC-ND). This license allows others to download the articles and share them with others as long as they credit you, but they can't change them in any way or use them commercially.

doi: 10.46327/msrjg.1.000000000000173

*****Published in August 28, 2020.

doi url: https://doi.org/10.46327/msrjg.1. 000000000000173

\section{BACKGROUND}

COVID-19 (Corona Virus Disease 2019) is a highly infectious disease with an incubation period of 2-14 days, caused by Sars-Cov-2 [1]. Prior to 2019, other less pathogenic viruses in the same Corona Viridae family as Covid-19 have caused epidemics particularly in Asia continent. These viruses include
SARS-1 and Meddle East Respiratory SyndromeVirus [2].

The current pandemic of Coronavirus disease (COVID-19) began in Wuhan, China in December 2019 [3]. As of 12 May 2020, it has spread to 212 countries and territories around the world with 4,137, 193 confirmed cases and 285, 760 deaths [3]. According to the Nigerian Centre for Disease Control 
(NCDC), the epidemic has spread to all the 36 states including the Federal Capital Territory (FCT) Abuja. As of $29^{\text {th }}$ July 2020, 41804 confirmed cases and 868 deaths have been reported with Lagos, FCT and Oyo State having the highest disease burdens in the country [4].

Most cases have remained asymptomatic, but such asymptomatic cases have the capacity to transmit the infection to others. Most of the recorded deaths have occurred in the elderly, the immunocompromised and those with premorbid conditions such as diabetes and hypertension. Consequently, COVID-19 was declared Public Health Emergency of Public Health Concern (PHEIC) in January 2020 and subsequently declared a pandemic disease by the World health Organization (WHO) on $11^{\text {th }}$ March 2020 [5].

The impact of COVID-19 pandemic has been catastrophic at individual, national and international levels. The world's socio-economy system has been severely disrupted with several people losing their jobs in the process. International travels and sporting events have been banned while international trade continues to suffocate. In addition, COVID-19 has overstretched the health systems of even the strongest nations of the world with several healthcare workers getting infected and dying from the disease. The global response activities have included suspension of international travels, compulsory isolation and treatment of cases and quarantine of suspect cases including travelers from COVID-19 endemic nations [6].

First COVID-19 case was reported in Nigeria on February 27th, 2020. Since then partial or complete lockdowns have been instituted in almost all the states of the Federation. This lockdown includes restriction of movements and indefinite closure of all schools as well as religious centers. This is undoubtedly associated with dire socio-economic consequences, having tremendous psychological implications on the general population and on the Nigerian students specifically. However, some proactive Nigerian institutions have commenced online classes, trainings, certifications, assessment, and evaluation to positively engage the students while they are staying at home. Yet, the psychological impacts of COVID-19 on Nigerian students have not been prioritized in the control measures so far deployed. The potential impacts on academic-performance and emotional effects of sudden shifts from interactive face-to-face system to online platform as a method of teaching have not been contextualized for the Nigerian students. This study sets out to provide information to bridge this gap in knowledge and to provide base-line data which can be useful for all-inclusive policy decisions in response to the COVID-19 pandemic. The specific objectives were to estimate the burden, assess coping strategies and identify the determinants of mental health status of the Nigerian students during COVID-19 pandemic.

\section{MATERIALS AND METHODS}

This cross-sectional study was conducted in Bowen University Iwo (BUI) located in Iwo town, Osun state Nigeria. BUI is a private University established and managed by the Nigerian Baptist Convention. The total population of the students in the University is 4,536 according to the University's website. The University has 7 colleges and 57 departments housed in a 1,300-acre campus. The study population included students in BUI. The study included only students who had stayed for a minimum of one semester on campus before the lockdown started, those with premorbid conditions such as those on drug rehabilitation were excluded from the study.

The sample size was calculated using the Leslie Kish formula for estimating single proportion in a population with less than 10,000 people. A standard normal deviate of 1.96 was used in the calculation and $43 \%$ of our respondents was assumed would be having some forms of mental issues due to the lockdown based on findings from a previous study conducted in Spain by Savitsky et al. (2020) [7]. The margin of error was set at $5 \%$, a $10 \%$ non-response rate was anticipated and corrected for. Thus, the minimum sample size estimated was 418 but 433 students participated in the study.

Multistage Sampling method was used in recruiting eligible respondents. Firstly, 2 out of the 7 colleges in the University were selected using simple random sampling technique (balloting). Next, the list of all the course/programs in the selected 2 colleges were obtained from College Provost Offices, and simple random sampling techniques (balloting) was used to select 4 courses/programs from the two colleges. The selected courses included Law, Medicine \&Surgery, BSc Nursing and BSc Physiotherapy. Proportionate sampling method was used to select eligible respondents from $1^{\text {st }}$ to $6^{\text {th }}$ year of study, taking cognizance of the male to female sex-ratio in each course level. 
The instrument for data collection in this study was a self-administered, semi-structured online questionnaire. The instrument collected information on respondents' socio-demographic characteristics, their student life during the ongoing COVID 19 pandemics, the psychological impact of COVID 19 and their coping strategies. The questionnaire was phrased in simple English devoid of medical terminologies for easy understanding of non-medical science students.

The questionnaire was pre-tested on 30 responders in a different population (students from Ladoke Akintola University of Technology Ogbomosho) from the study population. They were selected using convenience sampling method. The exercise helped to assess the internal consistency of the instrument. All ambiguous or poorly constructed questions were either re-phrased or removed based on the study objectives. Data were collected between April and May 2020.

Daily editing was done before the data were entered into Statistical Package for Social Sciences (SPSS, Version 21) for analysis. Data were presented in Tables and Charts. Continuous variables were summarized using Mean and Standard deviation while categorical variables were summarized using percentages. Chi-Square test was used to compare categorical variables at the bi-variate level. A stepwise binary logistic regression model was built at the multivariate level. Odds ratio (OR) and Confidence Intervals (CI) were obtained to assess the significant predictors of decreased psychological wellbeing due to the COVID-19 lockdown among the respondents. To assess the mental wellbeing of respondents, 13 questions were asked on their general mental healthrelated feelings, each were with four possible responses which were scored ranging from 1-4points. The responses were less than usual (1), not more than usual (2), rather more than usual (3), and much more than usual (4). Total scores of each respondent were calculated and the mean score computed. The total score attainable was 52points but the mean score was

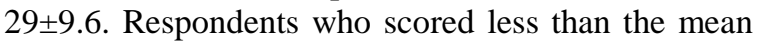
score were categorized as having decreased mental wellbeing.

Ethical approval to conduct the study was obtained from the Ethical Review Committee of Bowen University Teaching Hospital, Ogbomosho (BUTH/REC-061). Written consents were obtained from each respondent before they were allowed to participate in the study. Participation in the study was entirely voluntary and participants could opt out at any stage of the interview as they so wished. Responses from the interviewees were kept strictly confidential as the questionnaires were made anonymous and data collected were entered into passworded computers.

\section{RESULTS}

Four hundred and fifty questionnaires were administered but 433 were returned satisfactorily completed (96.2\% response rate).

Table 1 shows that the mean age of the respondents was $20.11 \pm 2.874$ years. Almost three-quarter $(72.7 \%)$ of the respondents were females with most $(62.4 \%)$ of them belonging to the 15-20-year agecategory. Almost half (48.5\%) of the respondents were medical students and $55.2 \%$ of them were in year 1-3 in their courses of study. Almost all $(96.3 \%)$ of the respondents were staying with their parents during the lockdown but $1.8 \%$ were staying alone in rented apartments. Overall, more than half $(50.8 \%)$ of the respondents were not satisfied with the shift to online method of learning due to the lockdown but almost half $(46.9 \%)$ of them preferred interactive online lecturing using Zoom or Webinar. 
Table I: Sociodemographic features of respondents and satisfaction with online studies

\begin{tabular}{|c|c|c|c|}
\hline \multicolumn{2}{|c|}{ Sociodemographic Features } & \multirow{2}{*}{$\begin{array}{c}\text { Frequency } \\
315\end{array}$} & \multirow{2}{*}{$\begin{array}{c}\text { Percent } \\
72.7\end{array}$} \\
\hline Gender & Female & & \\
\hline \multirow{6}{*}{ Present Age } & Male & 118 & 27.3 \\
\hline & $15-20$ & 270 & 62.4 \\
\hline & 21-25 & 149 & 34.4 \\
\hline & $26-30$ & 11 & 2.5 \\
\hline & 31-35 & 2 & 0.5 \\
\hline & $36-40$ & 1 & 0.2 \\
\hline Main course of study & Law & 65 & 15.0 \\
\hline & Medicine and Surgery & 210 & 48.5 \\
\hline & Nursing Science & 92 & 21.2 \\
\hline & Physiotherapy & 66 & 15.2 \\
\hline Years of study & $\begin{array}{l}1-3 \\
4-6\end{array}$ & $\begin{array}{l}239 \\
194\end{array}$ & $\begin{array}{l}55.2 \\
44.8\end{array}$ \\
\hline Where have you & A staff quarters & 1 & 0.2 \\
\hline predominantly been living & Family home & 417 & 96.3 \\
\hline since the onset of the & Friend's home & 3 & 0.7 \\
\hline COVID 19 pandemic & Rented accommodation & 8 & 1.8 \\
\hline & With relatives & 4 & 0.9 \\
\hline Students satisfaction & Satisfied & 213 & 49.2 \\
\hline with online studies & Not Satisfied & 220 & 50.8 \\
\hline \multirow{5}{*}{$\begin{array}{l}\text { Preferred method } \\
\text { of online lectures }\end{array}$} & None & 11 & 2.5 \\
\hline & Online with a video recording of the lecturer lecturing & 92 & 21.2 \\
\hline & $\begin{array}{c}\text { Online with an audio recording of the lecturer } \\
\text { lecturing }\end{array}$ & 75 & 17.3 \\
\hline & $\begin{array}{c}\text { Online with the lecturer lecturing in real-time (via } \\
\text { Zoom, Webinar,etc....) }\end{array}$ & 203 & 46.9 \\
\hline & Via presentation sent by lecturers & 52 & 12.0 \\
\hline
\end{tabular}

In all, 55\% of the respondents had decreased psychological wellbeing because of the lockdown (Fig. 1). Meanwhile, majority $(84.5 \%)$ of the respondents focused only on positive news as coping mechanism but $4.8 \%$ indicated interest to use substances to help them navigate the hard time (Fig. 2).

\section{Psychological Impact of the lockdown}

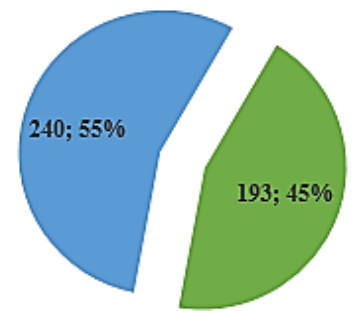

- Decreased levels of psychological wellbeing - Adequate psychological wellbeing Figure 1: Psychological impacts of the lockdown on respondents
Coping Strategies engaged by respondents

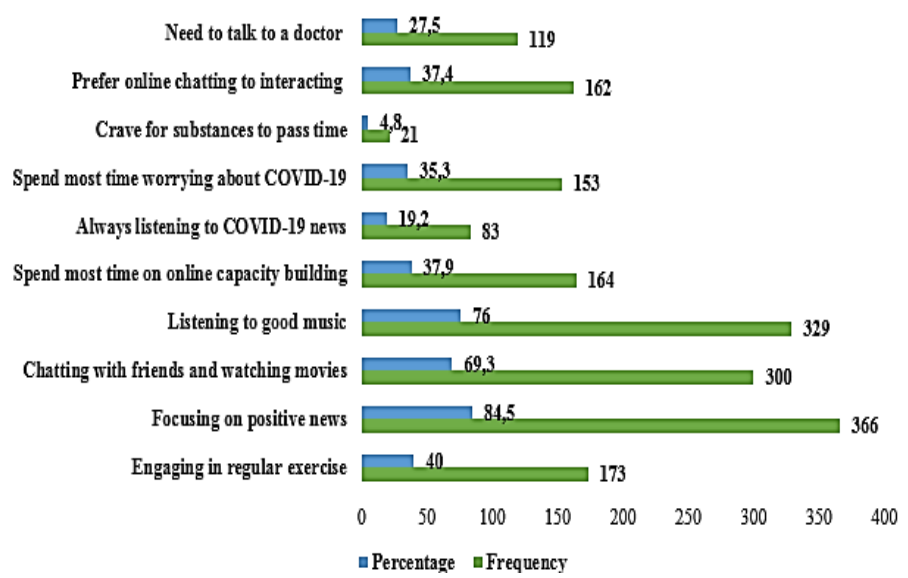

Figure 2: Coping strategies engaged by respondents (Multiple responses allowed) 
The proportion $(56.8 \%)$ of respondents with some degrees of psychological affectations due to the lockdown was significantly higher among students who were not satisfied with a switch to online teaching method (Table II). In Table III, respondents who spent most times chatting online with friends or watching films were $78 \%$ less likely to develop psychological issues compared to those who were not $(\mathrm{OR}=0.22,95 \%$ $\mathrm{CI}=1.37-3.59$ ). Similarly, respondents who focused on online capacity building during the lockdown period had $61 \%$ lesser odds of developing psychological problems compared to those who were not $(\mathrm{OR}=0.25,95 \% \mathrm{CI}=$ 0.25-0.61). However, respondents who were craving for substances use to cope with the stress of the lockdown were 2 times more likely to have decreased psychological wellbeing compared to students who were not itching to use substances $(\mathrm{OR}=1.50,95 \% \mathrm{CI}=0.55$ 4.05). Additionally, respondents who were not satisfied with online mode of teaching were 5 times more likely to have decreased psychological wellbeing compared to those who were $(\mathrm{OR}=5.34,95 \% \mathrm{CI}=4.13-9.18)$.

Table II: Association between respondents' sociodemographic status/satisfaction with online studies and psychological impact of the lockdown

\begin{tabular}{|c|c|c|c|c|c|c|}
\hline \multirow[t]{2}{*}{ Variable } & & \multicolumn{2}{|c|}{ Psychological impact } & \multirow{2}{*}{$\begin{array}{c}\text { Total } \\
433 \\
\text { n }(\%)\end{array}$} & \multirow[b]{2}{*}{$\mathbf{X} 2$} & \multirow[b]{2}{*}{$\mathbf{P}$} \\
\hline & & $\begin{array}{c}\text { Decreased levels of } \\
\text { psychological } \\
\text { wellbeing } \\
\mathrm{N}=193 \mathrm{n}(\%) \\
\end{array}$ & $\begin{array}{c}\text { Adequate } \\
\text { psychological } \\
\text { wellbeing } \\
\mathbf{N}=\mathbf{2 4 0} \text { n }(\%) \\
\end{array}$ & & & \\
\hline Gender & Female & $139(44.1)$ & $176(55.9)$ & $315(72.7)$ & 0.093 & 0.760 \\
\hline \multirow{6}{*}{ Present Age } & Male & $54(45.8)$ & $64(54.2)$ & $118(27.3)$ & \multirow{6}{*}{4.134} & \multirow{6}{*}{0.388} \\
\hline & $15-20$ & $124(45.9)$ & $146(54.1)$ & $270(62.4)$ & & \\
\hline & 21-25 & $66(44.3)$ & $83(55.7)$ & $149(34.4)$ & & \\
\hline & $26-30$ & $2(18.2)$ & $9(81.8)$ & $11(2.5)$ & & \\
\hline & 31-35 & $1(50)$ & $1(50)$ & $2(0.5)$ & & \\
\hline & $36-40$ & $0(0)$ & $1(100)$ & $1(0.2)$ & & \\
\hline \multirow[t]{4}{*}{ Main course of study } & Law & $28(43.1)$ & $37(56.9)$ & $65(15.0)$ & \multirow[t]{4}{*}{2.985} & \multirow[t]{4}{*}{0.394} \\
\hline & $\begin{array}{l}\text { Medicine and } \\
\text { Surgery }\end{array}$ & $87(41.4)$ & $123(58.6)$ & $210(48.5)$ & & \\
\hline & Nursing Science & $43(46.7)$ & $49(53.3)$ & $92(21.5)$ & & \\
\hline & Physiotherapy & $35(53.0)$ & $31(47.0)$ & $66(15.2)$ & & \\
\hline Year of study & $\begin{array}{l}1-3 \\
4-6\end{array}$ & $\begin{array}{c}110(46.0) \\
83(42.8)\end{array}$ & $\begin{array}{l}129(54.0) \\
111(57.2)\end{array}$ & $\begin{array}{l}239(55.2) \\
194(44.8)\end{array}$ & 0.455 & 0.500 \\
\hline \multirow{5}{*}{$\begin{array}{l}\text { Where have you } \\
\text { predominantly been living } \\
\text { since the onset of the } \\
\text { COVID } 19 \text { pandemic }\end{array}$} & A staff quarters & $1(100)$ & $0(0)$ & $1(0.2)$ & \multirow[t]{4}{*}{5.443} & \multirow[t]{4}{*}{0.245} \\
\hline & Family home & $189(45.3)$ & $228(54.7)$ & $417(96.3)$ & & \\
\hline & Friend's home & $1(33.3)$ & $2(66.7)$ & $3(0.7)$ & & \\
\hline & $\begin{array}{c}\text { Rented } \\
\text { accommodation }\end{array}$ & $1(12.5)$ & $7(87.5)$ & $8(1.8)$ & & \\
\hline & With relatives & $1(25.0)$ & $3(75.0)$ & $4(0.9)$ & & \\
\hline \multirow{2}{*}{$\begin{array}{l}\text { Students satisfaction with } \\
\text { online studies }\end{array}$} & Satisfied & $68(31.9)$ & $145(68.1)$ & $213(49.2)$ & \multirow[t]{2}{*}{27.145} & \multirow[t]{2}{*}{$0.000^{*}$} \\
\hline & Not Satisfied & $125(56.8)$ & $95(43.2)$ & $220(50.8)$ & & \\
\hline
\end{tabular}

*Significant at $\mathrm{p}<0.05$ 
Table III: Association between psychological impact and coping strategies

\begin{tabular}{|c|c|c|c|c|c|c|c|c|}
\hline \multirow{2}{*}{ Variable } & & \multicolumn{2}{|c|}{ Psychological impact } & \multirow[b]{2}{*}{$\begin{array}{c}\text { Total } \\
433 \mathrm{n}(\%)\end{array}$} & \multirow[b]{2}{*}{$\mathbf{X}^{2}$} & \multirow[b]{2}{*}{ P-value } & \multirow[b]{2}{*}{ OR } & \multirow[b]{2}{*}{$95 \% \mathrm{CI}$} \\
\hline & & $\begin{array}{c}\text { Decreased levels } \\
\text { of psychological } \\
\text { wellbeing }\end{array}$ & $\begin{array}{c}\text { Adequate } \\
\text { psychological } \\
\text { wellbeing }\end{array}$ & & & & & \\
\hline \multirow{2}{*}{$\begin{array}{l}\text { Engaging in regular } \\
\text { exercise }\end{array}$} & Yes & $84(49.0)$ & $89(51.0)$ & $173(40.0)$ & 1.849 & 0.174 & 1.51 & $0.98-2.31$ \\
\hline & No & $109(41.9)$ & $151(58.1)$ & $260(60)$ & & & & \\
\hline \multirow{2}{*}{ Focusing on positive news } & Yes & $158(43.2)$ & $208(56.8)$ & $366(84.5)$ & 1.886 & 0.170 & 0.93 & $0.51-1.69$ \\
\hline & No & $35(52.2)$ & $32(47.8)$ & $67(15.5)$ & & & & \\
\hline \multirow{2}{*}{$\begin{array}{l}\text { Chatting with friends and } \\
\text { watching movies }\end{array}$} & Yes & $151(50.3)$ & 149(49.7) & $300(69.3)$ & 13.119 & $0.000^{*}$ & 0.22 & $1.37-3.59$ \\
\hline & No & $42(31.6)$ & $91(68.4)$ & $133(30.7)$ & & & & \\
\hline \multirow{2}{*}{ Listening to good music } & Yes & $147(44.7)$ & $182(55.3)$ & $329(76.0)$ & 0.006 & 0.936 & 1.05 & $0.64-1.75$ \\
\hline & No & $46(44.2)$ & $58(55.8)$ & $104(24.0)$ & & & & \\
\hline \multirow{2}{*}{$\begin{array}{l}\text { Spent most time on online } \\
\text { capacity building }\end{array}$} & Yes & $51(31.1)$ & 113(68.9) & $164(37.9)$ & 19.402 & $0.000^{*}$ & 0.39 & $0.25-0.61$ \\
\hline & No & $142(52.8)$ & $127(47.2)$ & $269(62.1)$ & & & & \\
\hline \multirow{2}{*}{$\begin{array}{l}\text { Always listening to } \\
\text { COVID-19 news }\end{array}$} & Yes & $37(44.6)$ & $46(55.4)$ & $83(19.2)$ & 0.000 & 0.999 & 0.77 & $0.45-1.38$ \\
\hline & No & $156(44.6)$ & 194(55.4) & $350(80.8)$ & & & & \\
\hline \multirow{2}{*}{$\begin{array}{l}\text { Spent most time worrying } \\
\text { about COVID-19 }\end{array}$} & Yes & $71(46.4)$ & $82(53.6)$ & $153(35.3)$ & 0.322 & 0.571 & 0.88 & $0.55-1.41$ \\
\hline & No & $122(43.6)$ & $158(56.4)$ & $280(64.7)$ & & & & \\
\hline \multirow{2}{*}{$\begin{array}{l}\text { Crave for substances to } \\
\text { pass time }\end{array}$} & Yes & $14(66.7)$ & $7(33.3)$ & $21(4.8)$ & 4.361 & $0.037^{*}$ & 1.50 & $0.55-4.05$ \\
\hline & No & $179(43.5)$ & $233(56.5)$ & $412(95.2)$ & & & & \\
\hline \multirow{2}{*}{$\begin{array}{l}\text { Preferred online chatting } \\
\text { to interacting }\end{array}$} & Yes & $73(45.1)$ & $89(54.9)$ & $162(37.4)$ & 0.025 & 0.874 & 0.86 & $0.55-1.33$ \\
\hline & No & $120(44.3)$ & $151(55.7)$ & $271(62.6)$ & & & & \\
\hline \multirow{2}{*}{ Need to talk to a doctor } & Yes & $79(66.4)$ & $40(33.6)$ & $119(27.5)$ & 31.606 & 0.051 & 3.68 & $0.25-6.03$ \\
\hline & No & $114(36.3)$ & $200(63.7)$ & $314(72.5)$ & & & & \\
\hline $\begin{array}{l}\text { Students Satisfaction with } \\
\text { online lectures }\end{array}$ & $\begin{array}{l}\text { Yes } \\
\text { No }\end{array}$ & $\begin{array}{c}68(31.9) \\
125(56.8)\end{array}$ & $\begin{array}{l}145(68.1) \\
95(43.2)\end{array}$ & $\begin{array}{l}213(49.2) \\
220(50.8)\end{array}$ & 27.606 & $0.000^{*}$ & 5.34 & $4.13-9.18$ \\
\hline
\end{tabular}

*Statistically significant at $\mathrm{p}<0.05, \mathrm{OR}=\mathrm{Odds}$ Ratio, $\mathrm{CI}=$ Confidence Interval

\section{DISCUSSION}

This study examined impacts of COVID-19 pandemic on the psychological wellbeing of students in a Nigerian private university. The study shows that more than half of the students interviewed were not satisfied with online mode of teaching compared to the traditional face-to-face approach. Abedalla et al., revealed that students in Saudi Arabia preferred onthe-ground teaching to online education [8]. Also, a study conducted by Baloran, among students in Philippines shows that $59.25 \%$ of the respondents disagreed with the conduct of the Online-Blended Learning Approach [9]. Similarly, Ja'ashan revealed that majority of students in Saudi Arabia who went through online-blended learning expressed negative impressions due to slow internet connectivity [10]. In this digital age, ICT has made tremendous impacts in the teaching and learning environments globally. Thus, online mode of teaching has become remarkably popular and has been found to be convenient, less intimidating to students and flexible [11]. Thus, online approach comes in handy in engaging students in the era of COVID-19 pandemic in some tertiary institutions such as Bowen University, Iwo, Nigeria. However, online mode of teaching is not without some challenges. For instance, it is less interactive compared to the traditional mode of teaching [11]. Although some applications such as Zoom, Webex and Skype for Business allow for some degree of interactions, the 
physical student-to-instructor, and student-to-student interactions, which are key elements of formal education is weak using the online platform. Face-toface interactions help to create lasting bonds between the tutor and his students as well as between students themselves. It also allows for diffusion of culture, experiences, and knowledge among students.

In terms of academic performance of students, studies have shown a comparable effectiveness between online and the traditional face-to-face method [11]. Yet, it is still currently difficult to satisfactorily assess the attitudinal and skill domains of learning using the online method in many disciplines. Practical sessions and hands-on cannot be easily conducted and assessed using the online technologies. Thus, the quality of teachings on courses which require practical demonstrations such as most medical science courses cannot be guaranteed using the online platforms. Besides, online teachings encourage sedentary lifestyle/obesity among students and teachers, loneliness among the students, can cause eye problems due to glare of consistent use of laptops and is prone to technical issues (such as poor internet connections) which can easily disrupt lecture sessions.

In all, $55.0 \%$ of the respondents in the current study had decreased psychological wellbeing because of the lockdown. This is not an unexpected finding as previous studies had shown increased affectation of the psychological wellbeing of students and the general populations in different parts of the world since the onset of the global pandemic. For instance, a similar study conducted by Odrio-Gonzalez et al. among staff and students in a university in Spain revealed that $20-35 \%$ of the respondents reported symptoms of mental disorders during the pandemic period with undergraduate students being mostly affected [12]. During this pandemic, the prevalence of moderate and severe anxiety was $43 \%$ and $18 \%$ respectively among Nursing students in Israel as reported by Savitsky et al [7]. A study by Cao et al., revealed that $24.9 \%$ of College students in China experienced anxiety related disorders during the lockdown [1]. Also, Killgore et al., has demonstrated higher prevalence of loneliness leading to depression and suicidal ideation due to COVID-19 social isolation in the general population of USA [13]. Similarly, insomnia prevalence in the Greek population during COVID-19 pandemic was estimated at $37.6 \%$ for which loneliness, intolerance to uncertainty, depression, COVID-19 related worries were the predictive factors [14]. Increased occurrence of psychotic symptoms has also been reported in a caseseries study conducted in Madrid Spain by Rentero et al [15].

Specifically, it has been demonstrated that students have higher risks of having feelings of loneliness and are particularly prone to anxiety and depression when compared with the general population [1]. During this time of uncertainty and sudden shift to online teaching mode, it is unexpected to see psychological issues emerging more among students. The lockdown could have created feelings of loss of connections to friends and deprivation of the extracurricular activities which the students were enjoying while in the school environment. The uncertainties regarding their future and careers could have also worsened the situation leading to development of some mental issues amongst them.

Online chatting with friend/watching films and focusing on online capacity developments were identified in the current study as protective coping strategies against mental health affectations among students during the lockdown. Our finding was consistent with the results of the study conducted by Baloran in which chatting with friend's/family members and use of social media were some of the main coping strategies among the students interviewed [9]. Meanwhile, craving for substances as coping strategy and lack of satisfaction with online mode of teaching were the significant predictors of decreased psychological wellbeing among the respondents. In the study by Savitsky et al., stronger resilience and usage of humour were associated with significantly lower anxiety levels among Nursing students in Israel while substance use (e.g alcohol and sedative drugs) was associated with higher anxiety levels among them [7]. Craving for substances as coping strategy by some study participants in the current study during the pandemic indicates background psychological problems which could have been accentuated by the lockdown.

Thus, psychological wellbeing of the Nigerian students should be taken into cognizance and prioritized in the post-COVID-19 national rebuilding strategies. Asides online teachings, authors recommend that more vocational training sites be created online to productively engage students during the lockdown and beyond. Interactive youth-friendly online mental health programmes should be jointly sponsored by Ministries of Health and Education to reduce the impacts of the pandemic on the Nigerian students. A toll-free hotline should be provided for 
students who might need urgent medical consultations for mental health concerns. The universities running online courses in Nigeria should be more proactive in making online sessions more appealing and interactive to ensure students satisfaction with this mode of teaching. As the lockdown eases out, the Nigerian universities should make facilities available for early detection and prompt treatment of some of the students with signs and symptoms of decreased mental wellbeing, to avoid poor academic performances by them.

Study limitations: The study may not be totally free from self-reporting bias as it relied only on information provided by the respondents as opposed to clinical mental health assessments. However, the fact that the benefits of the results from the study were clearly explained to study participants prior to interviews and the assurance of confidentiality of their responses could have improve accuracy of information given and minimize this bias.

\section{CONCLUSION}

The COVID-19 pandemic has enormous effects on the mental health of the Nigerian students. All relevant stakeholders (including the university authorities) should work together in addressing this emerging public health problem as the fights against COVID-19 continues.

\section{ACKNOWLEDGMENTS:}

We hereby acknowledge the leadership of BUI who gave permission to conduct this study and the students who enthusiastically participated in the research.

\section{CONFLICT OF INTEREST/FUNDING:}

Authors declared no conflict of interests as no external funding was received in conducting this research.

\section{REFERENCES}

1. Huang C, Wang Y, Li X, Ren L, Zhao J, Hu Y, et al. Clinical features of patients infected with 2019 novel coronavirus in Wuhan, China. Lancet [Internet]. 2020 Feb 15 [cited 2020 Jul 10];395(10223):497-506. Available

from: /pmc/articles/PMC7159299/?report=abstract

2. Petrosillo N, Viceconte G, Ergonul O, Ippolito G, Petersen E. COVID-19, SARS and MERS: are they closely related? [Internet]. Vol. 26, Clinical Microbiology and Infection. Elsevier B.V.; 2020 [cited 2020 Jul 29]. p. 729-34. Available from: https://doi.org/10.1016/j.cmi.2020.03.026

3. The Chronicle of Higher Education. Shock, Fear, and Fatalism: As Coronavirus Prompts Colleges to Close, Students Grapple With Uncertainty - The Chronicle of Higher Education. [cited 2020 Jul 10]. Available from: https://www.chronicle.com/article/shock-fearfatalismas $/ 248240$

4. (NCDC) FR of N. NCDC Coronavirus COVID-19 Microsite [Internet]. [cited 2020 Jul 30]. Available from: https://covid19.ncdc.gov.ng/

5. Zhang Y, Jiang B, Yuan J, Tao Y. The impact of social distancing and epicenter lockdown on the COVID-19 epidemic in mainland China: A data-driven SEIQR model study. medRxiv [Internet]. 2020 Mar 6 [cited 2020 Jul 10];2019(December 2019):2020.03.04.20031187. Available from: https://doi.org/10.1101/2020.03.04.20031187

6. Sahu P. Closure of Universities Due to Coronavirus Disease 2019 (COVID-19): Impact on Education and Mental Health of Students and Academic Staff. Cureus. 2020 Apr 4;12(4).

7. Savitsky B, Findling Y, Ereli A, Hendel T. Anxiety and coping strategies among nursing students during the covid-19 pandemic. Nurse Educ Pract. 2020 Jun 2;102809.

8. Abedalla RW, Pinchot J, Samrgandi N N-MR. Saudi Students' Perceptions of Online Education versus Onground Education in Saudi Arabia | Request PDF [Internet]. [cited 2020 Jul 6]. Available from: https://www.researchgate.net/publication/289504855 Saudi_Students'Perceptions_of_Online_Education_v ersus_On-ground_Education_in_Saudi_Ầrabia

9. Baloran ET. Knowledge, Attitudes, Anxiety, and Coping Strategies of Students during COVID-19 Pandemic. J Loss Trauma [Internet]. 2020 May 22 [cited 2020 Jul 6];1-8. Available from: https://www.tandfonline.com/doi/full/10.1080/153250 24.2020.1769300

10. Hassan Ja'ashan MMN. Perceptions and Attitudes towards Blended Learning for English Courses: A Case Study of Students at University of Bisha. English Lang Teach. 2015;8(9).

11. AY Ni. Comparing the Effectiveness of Classroom and Online Learning: Teaching Research Methods. Vol. 19, 


\section{Choms}

Journal of Medical and Surgical Research

Source: Journal of Public Affairs Education. 2013.

12. Odriozola-González P, Planchuelo-Gómez Á, Irurtia MJ, de Luis-García R. Psychological effects of the COVID-19 outbreak and lockdown among students and workers of a Spanish university. Psychiatry Res. 2020 Aug 1;290:113108.

13. Killgore WDS, Cloonan SA, Taylor EC, Dailey NS. Loneliness: A signature mental health concern in the era of COVID-19. Vol. 290, Psychiatry Research. Elsevier Ireland Ltd; 2020. p. 113117.

14. Voitsidis P, Gliatas I, Bairachtari V, Papadopoulou K, Papageorgiou G, Parlapani E, et al. Insomnia during the COVID-19 pandemic in a Greek population. Vol. 289, Psychiatry Research. Elsevier Ireland Ltd; 2020. p. 113076.

15. Rentero D, Juanes A, Losada CP, Álvarez S, Parra A, Santana V, et al. New-onset psychosis in COVID-19 pandemic: a case series in Madrid. Vol. 290, Psychiatry Research. Elsevier Ireland Ltd; 2020. p. 113097. 